\title{
GEOGRAPHIC INFORMATION SYSTEM PROPOSES DETERMINATION OF BUSINESS LOCATION FEASIBILITY: CASE STUDY SMALL BUSINESS CULINARY IN PONTIANAK
}

\author{
Mochammad Ridwan Ristyawan \\ Faculty of Economics and Business of University of Tanjungpura, Indonesia \\ (m.ridwanristyawan@untan.ac.id)
}

\begin{abstract}
The growth of Small Medium Enterprises (SME's) has increased significantly in Pontianak. The new entry of small business resulted high level competition in culinary industry. A small business culinary could be closed to bankruptcy because the determination of business location was not feasible and settle. The customer would be difficult to find the location of the small business because due to non-fixed locations. The owner of small business often ignores the selection of strategic location. Therefore, it is important to establish the appropriate business location feasibility. Geographic Information System (GIS) is an information system that able to visualize the determining factors as a result analyzed spatial data. Analytical Hierarchy Processing (AHP) is a method that used into decision making process with multi criteria and multi alternatives. The spatial data of GIS is used by AHP to determine feasible location of small business. The criteria of spatial data are the number of competitors, infrastructure of location, distance of supplier, rental price of location, population density and traffic density. The spatial data of GIS result the visualization of spreading data in real condition on digital map subsequently be analyzed by AHP method to obtain recommended small business locations. The determination of hierarchy, criteria and priority rating location deliver recommendation the feasibility of culinary small business location.
\end{abstract}

Keywords: geographic information system, analytic hierarchy processing, small business.

\section{INTRODUCTION}

The small business significantly increased in Pontianak. In 2016, Dinas Koperasi, Usaha Mikro dan Perdagangan Kota Pontianak releases the number of 
SME's is 7812 units in Pontianak (data.go.id, 2017). Over a half of the number are small businesses in culinary industry. The large of number small business culinary and infiltration of new entry affected more keen competition.

The problem that faced the small business was sustainability of operational business. Frequently, the small business moved one to other locations to reach the customers. In consequence, the customers would be difficult to find the location of the small business. And the small business potentially lost the customers. The owner relied on intuition and prediction to place the small business. Therefore, it is important to establish the appropriate business location feasibility.

The business location is defined as the location of the store or retailer at a certain strategic location to maximize profit (Swastha, 2000). The feasible location of the small business culinary will attract the customers coming and buying the product. The location has the power to strengthen or weaken the company's strategic business (Heizer \& Render, 2011).

In site selection, people are often asked to estimate the potential market size for each candidate site $(\mathrm{Wu}, 2010)$. Determining of the small business culinary location have to base on accurate data capturing, managing, analyzing and displaying all forms of geographically references. Geographic Information System (GIS) offers spatial data location that have been used to reveal the criteria of feasible location for the small business. The spatial data of GIS result the visualization of spreading data in real condition on digital map.

The criteria of feasible location were analyzed by Analytical Hierarchy Process (AHP). AHP allows individual judgments in a reliable way and can finally overlay all the standardized criteria that help to make rankings based on locations (Ullah and Mansourian, 2015 in Rasli, 2016). The criteria are number of competitors, infrastructure of location, distance of supplier, rental price of location, population density and traffic density (Zaky, 2015). 
The integration of GIS and AHP methods provides a mechanism to thoroughly explore complicated problems and provide immediate and efficient feedback for users especially the determination of small business culinary location feasibility. The criteria were measured by GIS parameters and weighed by AHP analysis. The AHP analysis would resulted recommendation the feasible locations of small business culinary in Pontianak.

\section{KEY RESEARCH QUESTIONS}

The issues of research are to compete the keen competition of culinary business and to place the small business culinary onto suitable locations. According to the issues, the research focus on key research questions, there are:

1. How did to measure the criteria of the business location feasibility?

2. Where did the feasible location was select to place the small business culinary in Pontianak?

\section{LITERATURE REVIEW}

\section{Previous Researches}

Rasli et al (2016) investigated an integrated approach combining Analytical Hierarchy Process (AHP) and Geographic Information Systems (GIS) is adopted to provide weightages for each of the parameter layer by providing scoring and ranking to each parameter and conducting weighted overlay analysis to identify' suitable locations for six different types of parks.

Zaky (2015) conducted the research concerning decision support system determination of feasibility of location of culinary business branch with AHPTOPSIS method and the criteria of the business location feasibility. 


\section{Geographic Information System (Gis)}

GIS is an information system that acquires, stores, analysis and displays spatial data. In a strict sense, this is a computer system with centralized, storage, manipulation, and display of geographic reference information (Liu, 2017) GIS is the way in which the information is organized. There are two types of information: a graphical one indicating spatial distribution of the studied elements and another as a database to store attributes associated with these elements (Barliba et al, 2017).

\section{Analytical Hierarchy Process (Ahp)}

Rasli et al. (2016) convey that AHP is one of the multi criteria evaluation techniques that have been widely accepted by industries (Jalao et al., 2014) for solving support decision systems (Uyan, 2013).

Additionally, Rasli et al. (2016) stated that AHP enables the calculation of relative weight or importance of each of the parameters considered in the analysis by comparing the parameters to each other (Saaty, 2008 and Nefeslioglu et al., 2013). Both qualitative and quantitative measures can be considered in the process of selecting the best alternative from a number of choices of multiple criteria (Erden and Coskun, 2010).

\section{Development The Model}

Base on the previous literature review, this section will be designed for the developing model in this research. This model consists of three parts: defining of criteria measures base on GIS data, obtaining relative weights of criteria and sub criteria using AHP, and the small business location feasibility.

In Part 1, the research focused in defining criteria of feasible location for small business culinary. According to Zaky (2015), there are six criteria of determining small business culinary location that related to spatial data of GIS. The criteria will 
be developed as a model which emphasized six criteria: the number of competitors, infrastructure of location, distance of supplier, rental price of location, population density and traffic density.

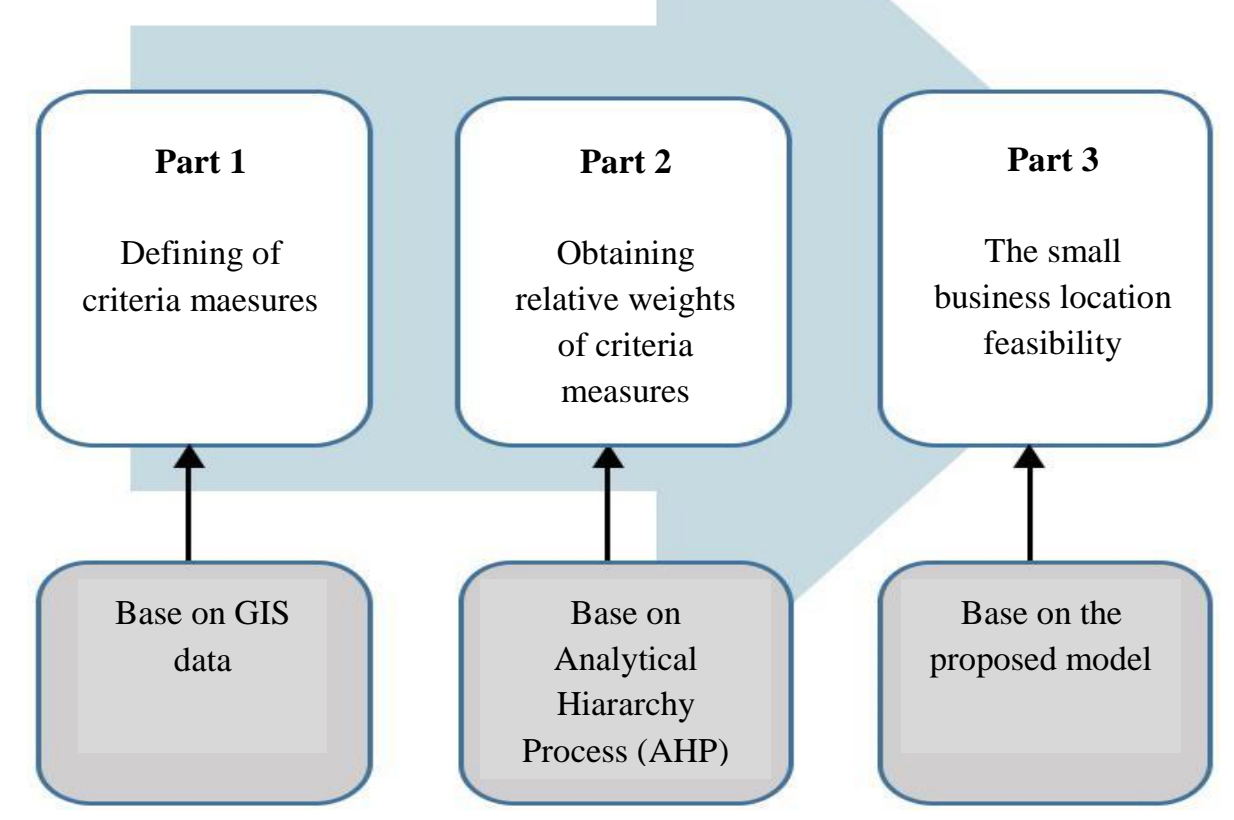

Figure 1. The Main Parts in The Application of the Proposal Model

Part 2 of model appropriately select the parameters to measure criteria of feasible location for small business culinary. For obtaining relative weights of criteria measures, Analytical Hierarchy Process (AHP) is enabled by this research.

And Part 3, the final section to evaluate score of small business culinary locations and give alternative option solution. The result of analysis will give recommendation locations of small business culinary which have optimal performance. 


\section{METHODOLOGY}

The methods of investigation are quantitative research. Type of research is experimental study which analyzes potential small business culinary locations.

\section{Study Area}

Pontianak is the capital of the Indonesian province of West Kalimantan, founded by Syarif Abdurrahman Alkadrie as a capital of Sultanate of Kadriyah in 23 Oktober 1771 / 14 Rajab 1185 Hijriah. Syarif Abdurrahman Alkadrie developed Pontianak as a trading port on the island of Borneo, occupying an area of $107.82 \mathrm{~km}^{2}$ in the delta of the Kapuas River (www.pontianakkota.go.id, 2017). It is located precisely on the equator, hence it is widely known as Kota Khatulistiwa (Equatorial City). The city center is actually less than 3 kilometers $(2 \mathrm{mi})$ south of the equator.

Pontianak Citycomprises six administrative districts, there are: East Pontianak, North Pontianak, Pontianak City, South Pontianak, South East Pontianak, and West Pontianak. Pontianak's map is shown Figure 2. The 2010 census enumerated Pontianak's population at 554,764. Pontianak is a diverse and multicultural city. Its population mainly consists of Malays, Tionghoa/ Indonesian Chinese and Dayak, with several minorities ethnics such as Bugis, Javanese, Madura, and etc. Most of Pontianak city's economy relies on industry, agriculture, and trade.

\section{Data}

The research used GIS data that adapted the criteria of the feasible small business location. 


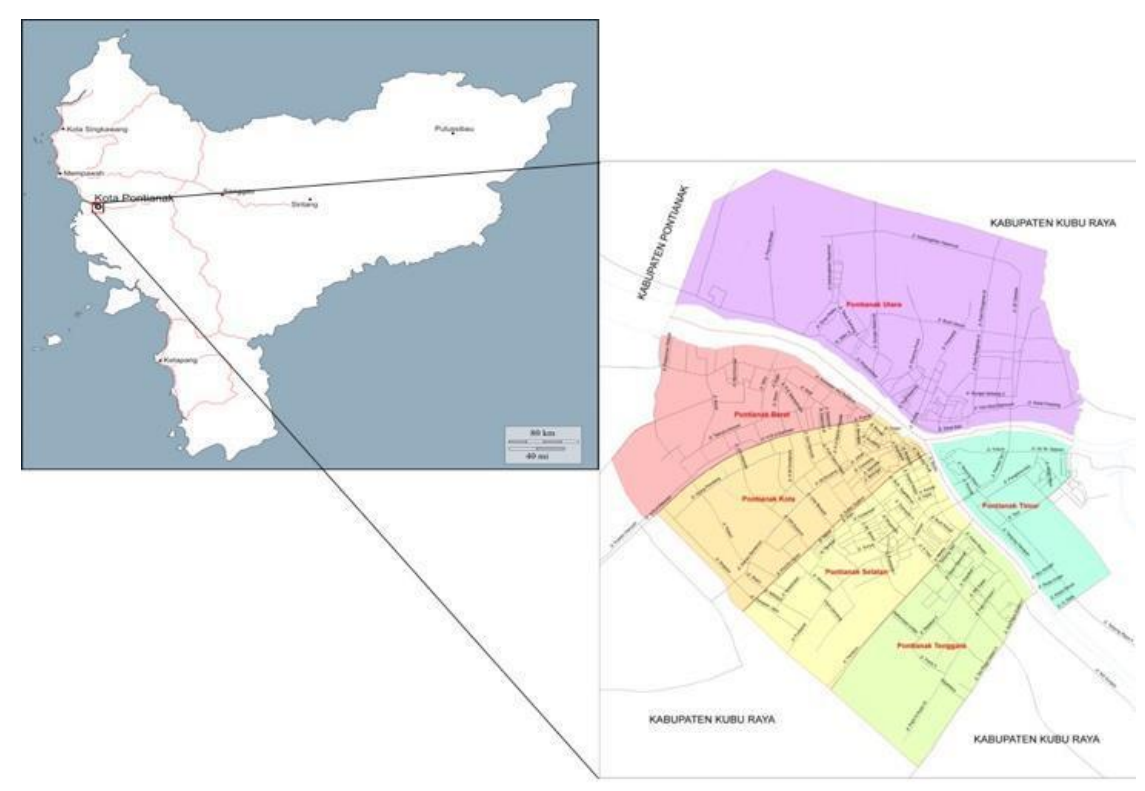

Figure 2. Pontianak's Map with Six Districts Source : www. Bappeda. Pontianakkota.go.id, 2017

\section{Site Selection}

The small business culinary locations require feasible conditions. The feasible criteria of locations are the the number of competitors,infrastructure of location, distance of supplier, rental price of location, population density and traffic density. Pontianak is divided into 3 main areas: center of city (located south of Kapuas River), middle area (located between Kapuas River and Landak River), and north area (located north of Kapuas River and Landak River). 2 spots locations of each main area were selected. And each area has a specific characteristic, therefore selecting small business culinary locations is analyzed by multi criteria and multi alternatives model. 


\section{Data Processing And Analysis}

GIS data of the locations content coordinates of geographic position and score of 6 criteria measurement (the number of competitors, infrastructure of location, the distance of supplier, rental price of location, population density and traffic density). Data will be analyzed by Analytical Hierarchy Process (AHP) to find best decision of selecting small business culinary location.

The score of criteria measurement base on calculation, as follows:

1. The number of competitors.

The criteria emphasize the number of competitors in culinary industry that located in radius 200 meters from the spots location.

2. Infrastructure of location.

The components of infrastructure are distribution of electricity and water supply.

3. The distance of supplier.

The distance of supplier related to transportation cost of distribution raw materials. The distance range was set $0-15 \mathrm{~km}$.

4. Rental price of location.

Rental price of location can be worth if it drives the sales and the profits of business, The interval rental price is $\mathrm{Rp} 0,-$ to $\mathrm{Rp} 2.000 .000,-$.

5. Population density.

The high level population density potentially increases affordability of customers buying.

6. Traffic density.

The traffic density determines the transaction probability of the customers.

The conversions of criteria data base on the observation of the specialist to get score of the locations. Table 1 show the conversions of criteria data to get the score that used the basis of decision making. 
Table 1

The Conversion of Criteria Data

\begin{tabular}{|c|c|c|}
\hline Criteria & Actual Data & Conversions \\
\hline \multirow{3}{*}{$\begin{array}{l}\text { The number of } \\
\text { competitors }\end{array}$} & $0-2$ actors & 5 \\
\hline & 3-5 actors & 3 \\
\hline & 6-8 actors & \\
\hline \multirow[t]{4}{*}{$\begin{array}{l}\text { Infrastructure of } \\
\text { location }\end{array}$} & $\begin{array}{c}\text { Electricity distribution and water supply are } \\
\text { insufficient }\end{array}$ & 1 \\
\hline & $\begin{array}{l}\text { Insufficient electricity distribution and } \\
\text { sufficient water supply }\end{array}$ & 2 \\
\hline & $\begin{array}{l}\text { Sufficient electricity distribution and } \\
\text { insufficient water supply }\end{array}$ & 3 \\
\hline & $\begin{array}{c}\text { Electricity distribution and water supply are } \\
\text { sufficient }\end{array}$ & 4 \\
\hline \multirow{3}{*}{$\begin{array}{l}\text { The distance of } \\
\text { supplier }\end{array}$} & $0-5 \mathrm{~km}$ & 5 \\
\hline & $5-10 \mathrm{~km}$ & 3 \\
\hline & $10-15 \mathrm{~km}$ & 1 \\
\hline \multirow[t]{3}{*}{ Rental price of location } & Rp 0,- to Rp 990.00,- & 5 \\
\hline & Rp 1000.000,- to Rp 2.000.00,- & 3 \\
\hline & Rp 2.000.00,- & \\
\hline \multirow[t]{5}{*}{ Population density } & 0 - 30 people & \\
\hline & $31-60$ people & 2 \\
\hline & 61 - 90 people & 3 \\
\hline & 91 - 120 people & 4 \\
\hline & $121-150$ people & 5 \\
\hline \multirow[t]{3}{*}{ Traffic density } & $0-20$ vehicles/minute & \\
\hline & 21 - 40 vehicles/minute & 3 \\
\hline & $41-60$ vehicles/minute & 5 \\
\hline
\end{tabular}




\section{Analytical Hierarchy Process (Ahp)}

AHP is a decision-making support system which breaks down complex multifactor or multi-criteria problems into a hierarchy (Saaty,1990). By definition, a hierarchy is a representation of a complex and multi-level problem, in which the first level is the purpose, followed by the factor level, criteria, sub-criteria, and so on until the final level of the alternative. AHP is often used as a problem-solving method compared to other methods, due to: a) it's hierarchal structure, as a consequence of the chosen criteria, all the way to the deepest sub-criteria, b) its ability to calculate validity to within the inconsistent tolerance limit of the many criteria and alternatives that are picked by the decision-taker, c) calculating the sensitivity analysis output of decision-making. Regardless of what the process is and how it is done, the most difficult stage to cope with will be what the decision-taker face in terms of implementation. 


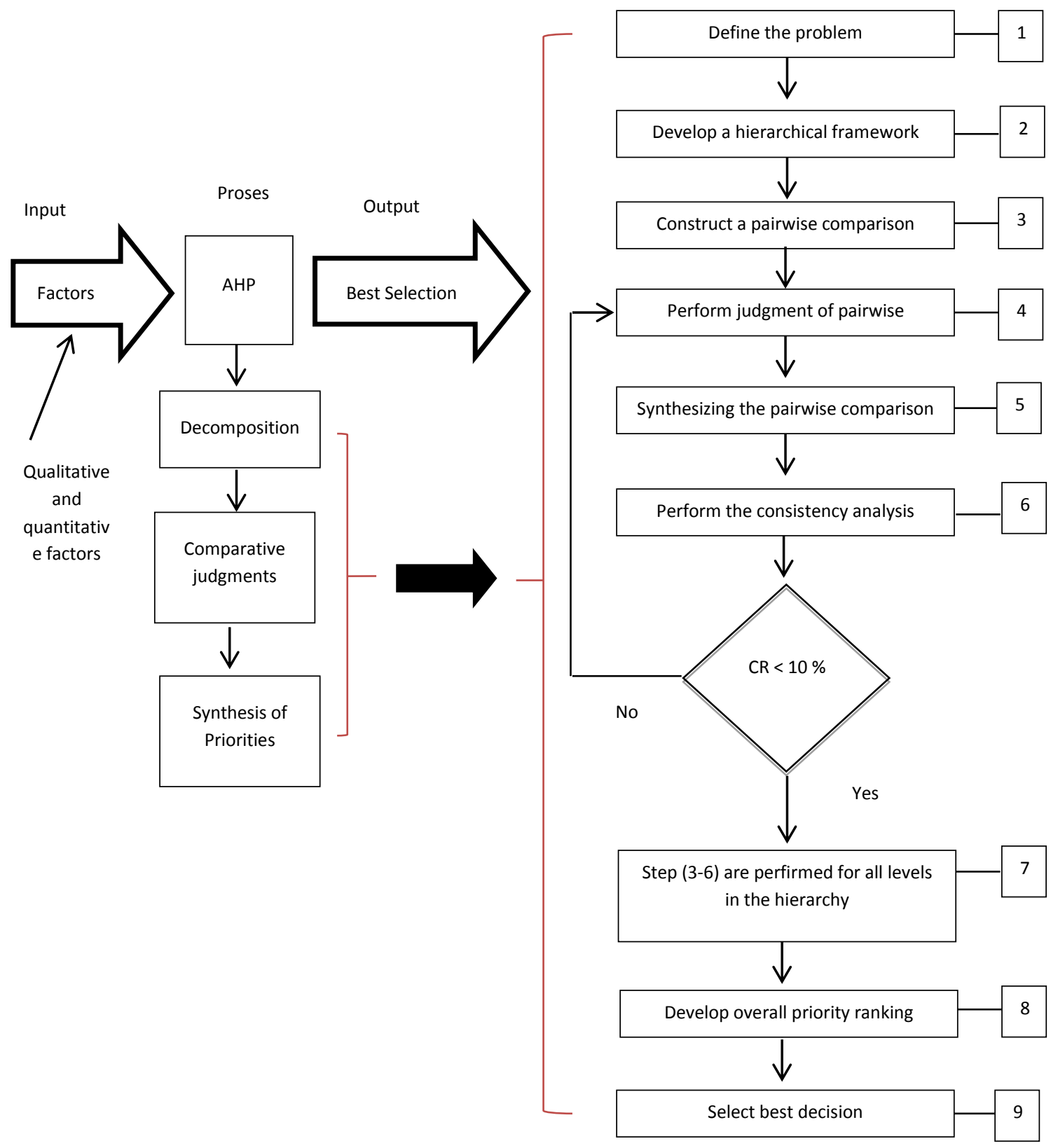

Figure 4. AHP Principles and Its Steps. (1)

Similarly, AHP will be used to construct models for simplifying the problem. These steps can be elaborated by structuring them in a more encompassing 9-step process. The process as shown in Figure 4. 
1. Define the Problem.

Defining the problem and determining the desired solution.

2. Develop a Hierarchy Model.

In this section, a hierarchy model for structuring design concept decisions using AHP is introduced.

Construct a Pair-wise Comparison Matrix. One of the major strengths of AHP is the use of pair-wise comparison to derive accurate ratio scale priorities. Pairwise comparisons are fundamental to the AHP methodology. Then, a pair-wise comparison matrix (size $\mathrm{n} \times \mathrm{n}$ ) is constructed for the lower levels with one matrix in the level immediately above. The pair-wise comparisons generate a matrix of relative rankings for each level of the hierarchy. The number of matrices depends on the number elements at each level. The order of the matrix at each level depends on the number of elements at the lower level that it links to.

3. Perform Judgement of Pairwise Comparison.

Pair-wise comparison begins with comparing the relative importance of two selected items. There is $n \times(n-1)$ judgments required to develop the set of matrices in step 3.

4. Synthesizing the Pairwise Comparison. To calculate the vectors of priorities, the average of normalized column (ANC) method is used. ANC is to divide the elements of each column by the sum of the column and then add the element in each resulting row and divide this sum by the number of elements in the row (n). This is a process of averaging over the normalized columns.

In mathematical form, the vector of priorities can be calculated as:

$$
W_{I}=\frac{1}{n} \sum_{j}^{n}=1 \frac{a i j}{\sum_{j}^{n} a i j}, i j=1,2, \ldots n
$$

For instance, the calculation for the first priority vector as follows. 
5. Perform the Consistency.

Since the comparisons are carried out through personal or subjective judgments, some degree of inconsistency may be occurred. To guarantee the judgments are consistent, the final operation called consistency verification, which is regarded as one of the most advantages of the AHP, is incorporated in order to measure the degree of consistency among the pairwise comparisons by computing the consistency ratio (CR).

6. Performed for All Levels in the Hierarchy Model.

As the value of $C R$ for all sub-criteria and alternatives is less than 0.1 , the judgements are acceptable.

7. Develop Overall Priority Ranking.

After the consistency calculation for all levels is completed, further calculation of the overall priority vector to select the best design concept must be performed.

8. Selection of the Best Design Concept. This step shown result of selection.

\section{APPLICATION THE MODEL}

\section{Gis Data Analysis}

GIS gives two type of information, they are spatial and descriptive data. Spatial data were obtained from the rasterizing map. Descriptive data were obtained from analyzing spots of location on the map.

There are 6 alternative locations of small business culinary that represent 3 main areas in Pontianak. The alternative locations are Jalan Sepakat 2, Jalan Daya nasional, Jalan Tanjungraya 2, Jalan Panglima Aim, Siantan Market, and Jalan Khatulistiwa. The spots of alternative locations were shown at Figure 5. 


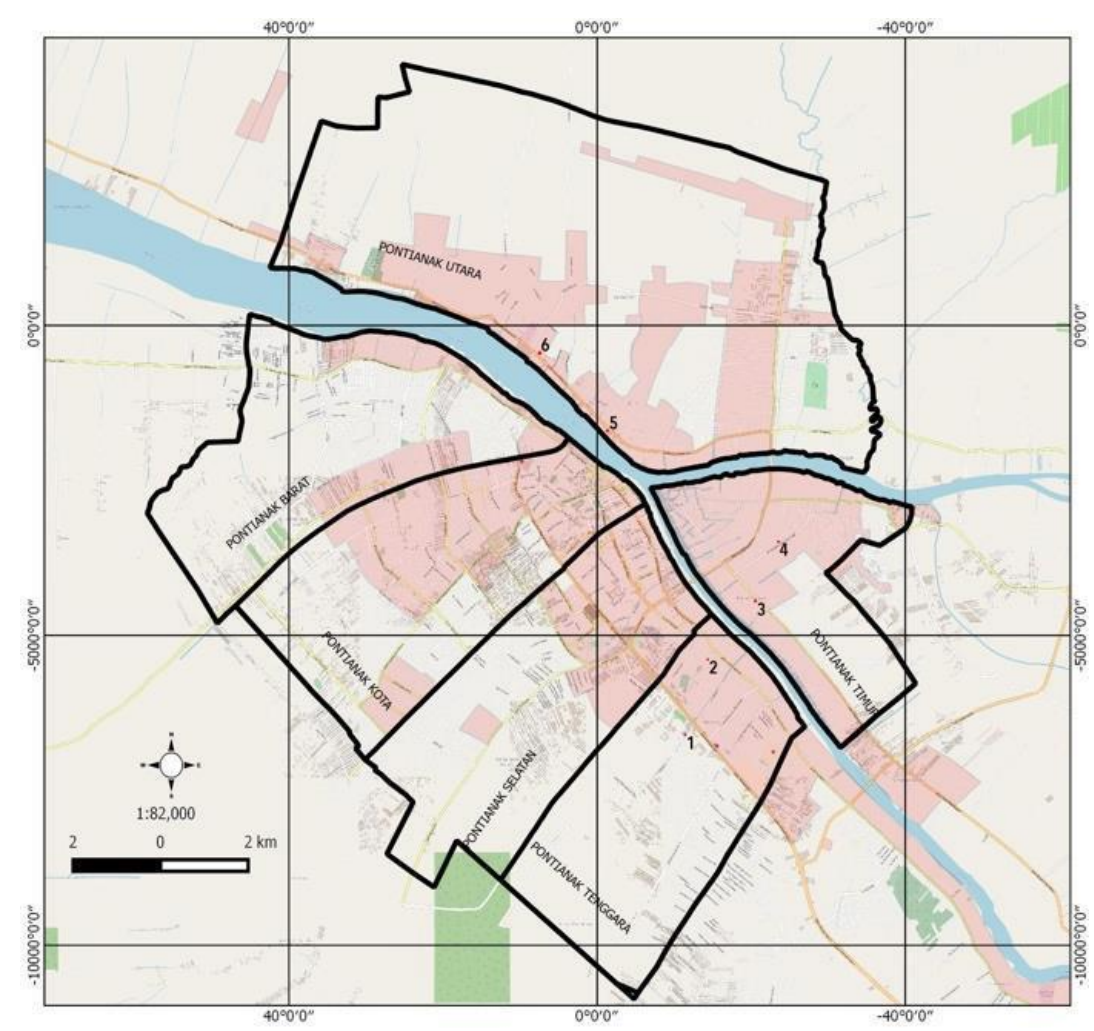

Figure 5. 6 Alternative Locations of Small Business Culinary in Pontianak

6 Alternative Locations Were Numbered As Follows:

1. Jalan Sepakat 2

2. Jalan Daya Nasional

3. Jalan Tanjungraya 2

4. Jalan panglima Aim

5. Siantan Market

6. Jalan Khatulistiwa

The alternative locations were measured by weighting of the criteria. Each location had score that according to 6 weighted criteria of conversion data. The result of weighting the alternatives locations was shown in Table 2. 
Table 2

Score of The Alternative Locations

\begin{tabular}{|l|l|l|l|l|l|l|}
\hline \multirow{2}{*}{ Alternative Location } & \multicolumn{7}{|c|}{ Criteria } \\
\cline { 2 - 7 } & $\mathbf{1}$ & $\mathbf{2}$ & $\mathbf{3}$ & $\mathbf{4}$ & $\mathbf{5}$ & $\mathbf{6}$ \\
\hline Jalan Sepakat 2 & 1 & 4 & 5 & 1 & 5 & 5 \\
\hline Jalan Daya Nasional & 1 & 3 & 4 & 3 & 5 & 3 \\
\hline Jalan Tanjungraya 2 & 2 & 2 & 3 & 3 & 4 & 3 \\
\hline Jalan Panglima Aim & 2 & 3 & 3 & 3 & 4 & 3 \\
\hline Siantan Market & 2 & 2 & 1 & 5 & 3 & 3 \\
\hline Jalan Khatulistiwa & 3 & 2 & 1 & 5 & 3 & 3 \\
\hline
\end{tabular}

The descriptive data of locations were analyzed to AHP that aimed to obtained score each locations.

\section{Result Of Ahp Application}

The analysis of data had been used AHP software application. The AHP software application can be shown at Figure 6. The score of the alternative locations were inserted the AHP software application with the result that score of AHP. For example, the score of Jalan Sepakat 2 was shown at Figure 7.

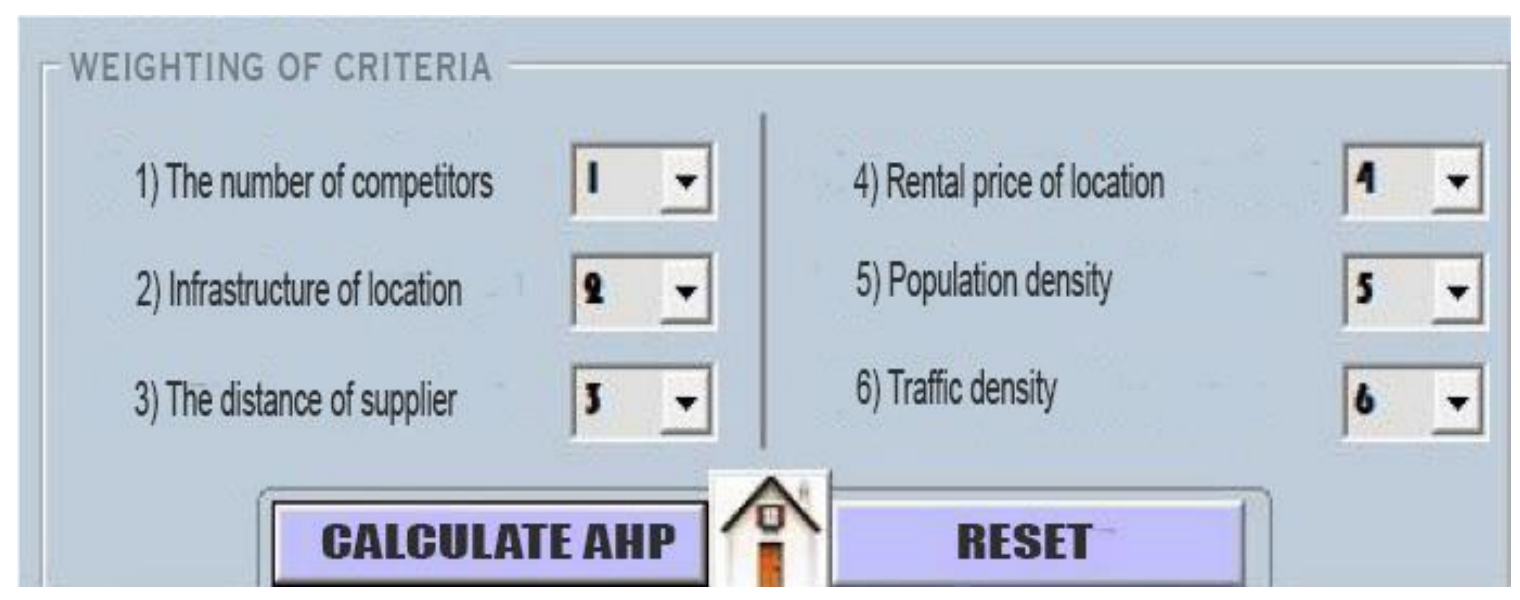

Figure 6. AHP Software Application 


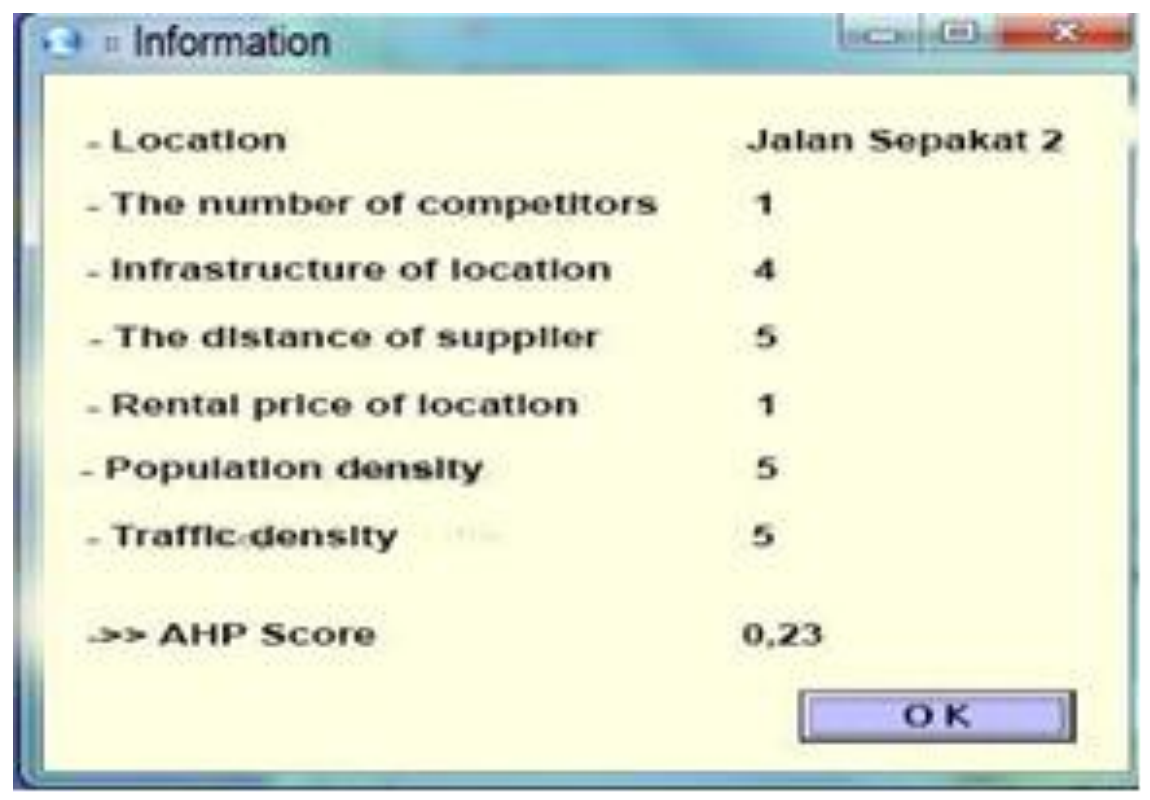

Figure 7. AHP Score of Alternative Locations

According to AHP Software Application, the AHP score of alternative locations were shown Table 3.

Table 3

AHP Score of Alternatives Locations

\begin{tabular}{|c|l|c|c|}
\hline No & Alternative Locations & AHP Score & Rank \\
\hline 1 & Jalan Sepakat 2 & 0,23 & 6 \\
\hline 2 & Jalan Daya Nasional & 0,31 & 4 \\
\hline 3 & Jalan Tanjungraya 2 & 0,28 & 5 \\
\hline 4 & Jalan Panglima Aim & 0,33 & 3 \\
\hline 5 & Siantan Market & 0,37 & 1 \\
\hline 6 & Jalan Khatulistiwa & 0,35 & 2 \\
\hline
\end{tabular}

\section{DISCUSSION}

According to Table 3, Siantan Market that has AHP score 0,37 was the most feasible location for small business culinary in Pontianak. Jalan Sepakat 2 is is lowest AHP score with the result that it is a last alternative of small business culinary 
location. Jalan Khatulistiwa could be the second priority of all alternative locations. The rank feasible locations of small small business culinary according to AHP score are:

1. Siantan Market

2. Jalan Khatulistiwa

3. Jalan Panglima Aim

4. Jalan Daya Nasional

5. Jalan Tanjungraya 2

6. Jalan Sepakat 2

Jalan Daya Nasional was more feasible rather than Jalan Sepakat 2 in center city area of Pontianak. And in middle area, Jalan Panglima Aim was more feasible rather than Jalan Tanjungraya 2.

There are 3 alternative locations of small business culinary every main area of Pontianak: Siantan Market, Jalan Panglima Aim, and Jalan Daya Nasional.

\section{CONCLUSIONS}

The GIS of location significantly help entrepreneur to determine the small business location in Pontianak. Base on the discussion section, the feasible location of small business culinary can be concluded:

1. Siantan Market was the most feasible location to place the small business culinary in Pontianak. The second alternative locations was Jalan Khatulistiwa. Both location are in north area of Pontianak.

2. The feasible location in center city of Pontianak was Jalan Daya Nasional, meanwhile the feasible location of middle area of Pontianak was Jalan Panglima Aim. 


\section{REFERENCES}

Bappeda. 2016. “Data UMKM Kota Pontianak". Bappeda Kota Pontianak.

Barliba, F.C., Gheorghescu, L.C., and Moscovici, Anca-Maria. 2017. "The Advantage of Using Mobile GIS Technology. Research Journal of Agricultural Science. Banat University of Agricultural Scienceand Veterinary Medicine Timisoara.

Heizer,J.,\&Render,B.2011.“Operations Management: Tenth Edition”. Pearson, New Jearsey.

Liu, Xiangfa. 2017. “Application of GIS Technology and Sensor Technology in Tunnel Deformation Mapping". Weifang University of Science and Technology, Shandong, China.

Rasli, F.N., Kanniah, K.D., Muthuveerapppan, C., and Ho, C.D. 2016. “An Integrated Approach of Analytical Hierarchy Process and GIS for Site Selection of Urban Parks in Iskandar Malaysia". International Journal of Geoinformatics. Geoinformatics International.

Saaty, T. L. 1990, "How to make a decision: The Analytic Hierarchy Process". European Journal of Operational Research, 9-26.

Swastha, B. 2000, "Pengantar Bisnis Modern". Liberty, Jakarta.

Wu, Junjie., Chen, Jian., and Ren, Yili. 2010. “GIS Enabled Service Site Selection: Environmental Analysis and Beyond". Information Systems Frontiers. Springer Science \& Business Media B.V.

Zaky, I. M. 2015. “Sistem Pendukung Keputusan Penentuan Kelayakan Lokasi Cabang Usaha Kuliner dengan Metode AHP- TOPSIS". Universitas Brawijaya, Malang.

www.bappeda.pontianakkota.go.id. "Pontianak's Map with Six Districts". Downloaded at April 10, 2017

www.data.go.id. "Data UMKM Kota Pontianak". Downloaded at May 14, 2017

www.pontianakkota.go.ig. "Profil Kota Pontianak". Downloaded at April 12, 2017 